\title{
The Water-Energy-Environment Nexus in the Great Lakes Region: The Case for Integrated Resource Planning
}

\author{
Vincent C. Tidwell ${ }^{1} \&$ Victoria Pebbles ${ }^{2}$ \\ ${ }^{1}$ Earth Systems Analysis Department, Sandia National Laboratories, Albuquerque, USA \\ ${ }^{2}$ Great Lakes Commission, Ann Arbor, USA \\ Correspondence: Vincent Tidwell, Sandia National Laboratories, PO Box 5800:MS1137, Albuquerque, NM \\ 87185, USA. Tel: 1-505-844-6025. E-mail: vctidwe@ sandia.gov
}

Received: November 15, $2014 \quad$ Accepted: November 29, $2014 \quad$ Online Published: September 24, 2015

doi:10.5539/eer.v5n2p1

URL: http://dx.doi.org/10.5539/eer.v5n2p1

The research is financed by the Great Lakes Commission

\begin{abstract}
Water is a critical element of electric power production in the U.S., particularly in the Great Lakes Basin region. Thermoelectric power generation accounts for the majority of all water withdrawals in the Basin, in large part due to the comparatively heavy concentrations of coal and nuclear power generation that utilize open-loop cooling. This paper explores how different energy generation portfolios could affect the water resources of the Great Lakes Basin. The suite of power generation scenarios analyzed reflects a range of potential outcomes resulting from the implementation of key national and regional energy and environmental policies for the electric power industry. These policies include U.S. EPA's pending power plant cooling water intake standards, state renewable energy portfolio standards, possible climate change legislation, and the 2005 Great Lakes regional water resource agreement (Great Lakes and St. Lawrence River Basin Water Resources Compact of 2005; Public Law 110-342). Five scenarios were analyzed, resulting in different levels and intensities of total water use (withdrawal and consumption) in hydrologically-sensitive watersheds. These results confirm the close relationship between water and energy in the Great Lakes, and point to the need to take into account water resource impacts in designing future energy and environmental policies.
\end{abstract}

Keywords: Energy-Water Nexus, Environmental Policy, Renewable Energy, Great Lakes

\section{Introduction}

The Great Lakes Basin is home to more than 580 power plants with a combined capacity of over 69,000 megawatts (U.S. Energy Information Administration 2009a). More than $80 \%$ of this power generation involves a steam cycle fired by coal, natural gas or nuclear fuels. As over $62 \%$ of this generation uses open-cycle cooling (a water intensive process in which cooling water flows from its source through the plant condenser and then directly back to its source), the electric power sector draws more water from the Basin than any other sector. The U.S. Geological Survey estimates that thermoelectric power accounts for 98.0 million cubic meters of water withdrawals per day $\left(\mathrm{Mm}^{3} / \mathrm{d}\right)$, or $76 \%$ of total water withdrawals in the Great Lakes Basin (Kenny et al., 2009). The majority of these withdrawals, $79 \%$, come directly from the Great Lakes.

Natural variability in water supply, policies governing water use, and technological evolution are important factors in defining the efficiency of power generation (Macknick et al., 2012). At the same time, these variations in energy sources and their associated technologies impact the quality and quantity of basin water supply, ultimately affecting consumers. Recent advances in Great Lakes water resource management policy specifically, the Great Lakes and St. Lawrence River Basin Water Resources Compact of 2005 (GLSLR Compact) - reflect a growing appreciation for such linkages and a desire to improve our understanding of how water use affects the functional integrity of the Great Lakes Basin ecosystem.

The objective of this paper is to explore the implications of potential national and regional policies on the energy-water-environment nexus in the Great Lakes Basin. Policies considered include U.S. EPA's pending power plant cooling water intake standards, state renewable energy portfolio standards, possible climate change legislation, and the GLSLR Compact. Alternative future power generation portfolio scenarios are constructed to 
reflect the complicated and variable policy space facing decision makers in the Basin. Ecologically-sensitive watersheds are identified in a region that generally has plentiful water resources, providing a framework for observing measurable impacts on water resources from water used for power generation. From this platform new information is presented on how changes in the type of power generation could affect these sensitive watersheds in the future - as well as the conditions that are likely to increase in frequency as demands on the region's natural resources increase with population growth. This study concludes with a review of relevant water and energy policies as well as associated institutional gaps and opportunities for improvement, offering a pathway to better integrate water resource considerations into energy policy and electric power resource planning. The work documented here is part of a larger study conducted by the Great Lakes Commission (2011).

\section{Method}

\subsection{National and Regional Policies}

Several energy policies have garnered particular attention in the past several years, due to the far reach of their potential impacts, including 1) EPA Clean Water Act Cooling Water rules, 2) State Renewable Portfolio Standards, and 3) Federal Climate Change Carbon Standards. These policies may not only affect the evolution of the energy sector, but could also shape future water demands and the scope of environmental impacts.

Section 316(b) of the Clean Water Act regulates cooling water intake structures by way of National Pollutant Discharge Elimination System (NPDES) permitting. This regulation is intended to minimize impingement and entrainment impacts to fish and other aquatic life posed by cooling water intake structures. The proposed policy contains three components. First, to curb impingement of fish against intake screens, existing facilities that withdraw more than $25 \%$ of their water for cooling purposes and are designed to intake more than $7.5 \times 10^{-3}$ $\mathrm{Mm}^{3} / \mathrm{d}$ would be subject to either numeric mortality standards or flow velocity limits. Second, to address entrainment at existing facilities with withdrawal rates above $0.5 \mathrm{Mm}^{3} / \mathrm{d}$, permitting authorities would be authorized to select a site-specific "best technology available". Third, to achieve prospective entrainment reductions, the proposal would require new electricity generation units at existing facilities (including replacement units, repowered units, and rebuilt units) to install closed-cycle cooling systems or, alternately, technology which reduces intake to closed-cycle equivalent volumes. This technology requirement already applies to new facilities (U.S. Environmental Protection Agency, 2012).

All states in the Great Lakes region have renewable energy targets established by state legislation, known as Renewable Portfolio Standards (RPS). RPSs require that utilities generate a certain amount of energy from renewable sources, or fulfill a certain percentage of their retail electricity sales with renewable energy or renewable energy credits (RECs). RPSs vary in several ways: the types of energy that is considered "renewable"; who must comply; and the standard - the percentage of renewables that is required to be met, according to a specific schedule. Some RPSs also include a "set-aside" or "carve-out" that requires utilities to meet the RPS using a specific renewable resource. Table 1 summarizes RPS standards in the eight Great Lakes states.

Growing concern over global warming and associated climate change has prompted interest in carbon capture and sequestration (CCS) as a means of reducing greenhouse gas emissions. Fossil-based thermoelectric power production is an important contributor to atmospheric greenhouse gas concentrations, accounting for $39 \%$ of total $\mathrm{CO}_{2}$ emissions (U.S. Environment Protection Agency 2011). Efforts to limit greenhouse gas emission standards had previously been proposed in the form of the American Clean Energy and Security Act (H.R. 2454, a.k.a. the former Waxman-Markey bill) and the Clean Energy Jobs and American Power Act (S. 1722, a.k.a. the former Kerry-Boxer bill).

\subsection{Energy Scenarios}

To explore potential implications of these policies five alternative energy futures, termed scenarios, have been developed. Each scenario is designed to explore tradeoffs in terms of water withdrawal, water consumption, environmental vulnerability, and GLSLR Compact permitting across the three energy policies described above.

Business as Usual (BAU): This scenario assumes that our energy future will look much like it does today. The BAU scenario assumes that there will be no changes to the current policies regulating power plant intake structures or greenhouse gas (GHG) emissions, nor does the scenario assume any reduction in water generation from the increased use of natural gas or renewables. Rather, the scenario assumes that the fuel mix remains unchanged, with construction of coal and nuclear capacity meeting roughly $55 \%$ of new electricity demand. The scenario also assumes that the cooling mix will remain unchanged from that of the 2009 fleet; $62 \%$ open-loop, $31 \%$ closed-loop cooling tower, and 7\% closed-loop cooling pond (Great Lakes Commission, 2011). Likewise, source water for plants is maintained according to the current distribution, specifically: $79 \%$ Great Lakes, $18 \%$ 
other surface water, and 3\% groundwater (Great Lakes Commission, 2011). Finally, this scenario assumes that both population and electricity demand will grow at projected reference rates (U.S. Census Bureau 2009; U.S. Energy Information Administration 2009a).

No New Open-Loop Cooling (NNOLC): This case uses the same assumptions as the BAU scenario, with one exception: no new power plant constructed would utilize open-loop cooling.

Open-Loop Cooling Prohibited (OLCP): In this scenario, open-loop cooling intake structures on both new and existing power plants are prohibited. Existing plants with open-loop cooling are either retrofitted to closed-loop, or retired. The scenario assumes the retiring of any plant over 35 years old with a capacity factor (the percent of time that the power plant operates in an average year) of $20 \%$ or lower. All other assumptions are similar to those in the BAU scenario.

Renewable Portfolio Standard (RPS): This scenario used the same assumptions as the NNOLC case, except that the future fuel mix in newly constructed plants favors renewables. Specifically, the scenario assumes that new plant construction is limited to 50\% wind, 25\% biopower, and 25\% Natural Gas Combined-Cycle (NGCC). This mix is very optimistic in terms of water resources impacts (e.g., low water use); thus, this RPS scenario represents a near best case alternative in terms of reductions in future thermoelectric water use.

Carbon Capture and Sequestration (CCS): This scenario assumes that future GHG levels must be reduced to $26 \%$ of the levels present in 2009 (consistent with U.S. Environment Protection Agency 2009 projections of previously proposed climate legislation). The scenario assumes that new plant construction follows the fuel mix of the RPS scenario, while cooling type mix associated with new plant construction follows that of the NNOLC case. The CCS case assumes that both existing (retrofitted) and new coal-fired power plants incur a 30\% parasitic energy loss (electricity needed to capture the $\mathrm{CO} 2$, compress it and inject underground for long term storage) due to implementation of carbon capture and sequestration (CCS), while a $15 \%$ loss is associated with natural gas and oil-fired plants (National Energy Technology Laboratory 2009). Associated water use factors were taken from Macknick et al. (2012).

\subsection{Great Lakes Energy-Water Model}

The Great Lakes Energy-Water (GLEW) model was adapted from a model of the contiguous U.S. developed by Tidwell et al. (2012), formulated within a system dynamics architecture and implemented within the commercial software package Studio Expert 2008, produced by Powersim, Inc. (www.powersim.com). The model is designed to operate on an annual time step over a 26 year planning horizon, from 2009 to 2035. The spatial extent of the model is defined both by the Great Lakes watershed as well as by the accompanying energyshed (the geographic area over which electric power used in the Great Lakes Watershed is produced). The GLEW model is organized according to four interacting modules: electric power production, thermoelectric water demand, non-thermoelectric water demand, and environmental health. A more detailed description of the model is provided in Tidwell et al. (2012).

The electric power production module of GLEW simulates the demand for power, as well as the new power plants constructed to meet growing demand for power. Future demand for electric power is based on the 2009 Annual Energy Outlook (U.S. Energy Information Administration 2009a), and distributed according to the five Electricity Market Module Regions (EMMR) that intersect the Great Lakes watershed. Electricity generation is modeled at the power plant level for the 583 plants recently in operation in the Great Lakes watershed (U.S. Energy Information Administration 2009a). According to the model, new electricity demand is first satisfied with electric capacity currently under construction as reported by EMMR (U.S. Energy Information Administration 2009a), while additional construction is apportioned by fuel mix according to the five different future build-out scenarios described below. Siting of new power plants is accomplished in such a way as to maintain the 2009 (U.S. Energy Information Administration 2009a) ratio of local watershed electric production to Great Lakes watershed production. This simple treatment assumes that future power plants will be sited so as to take advantage of existing fuels, transportation, and/or electricity transmission infrastructure. The electric power production module also simulates the retirement and/or retrofitting of power plants based on the age of the plant, its capacity factor, and changes to environmental policy.

Water withdrawal and consumption are calculated by the thermoelectric water demand module, based on power plant fuel type, cooling type, implementation of CCS, and associated production. For new power plants this calculation is accomplished by multiplying the production rate by the associated water withdrawal factor and water consumption factor. Each type of plant and its associated cooling technology has a unique water use factor (median values given by Macknick et al., 2012). Estimates of water withdrawal and consumption values at existing plants were developed from a variety of sources, including information available through the EIA's 
Form-767 (U.S. Energy Information Administration 2009b), Form EIA-860 (U.S. Energy Information Administration 2009c) the National Energy Technology Laboratory's Coal Power Plant Database (National Energy Technology Laboratory 2007), and through state departments of water resources and the U.S. Geological Survey (USGS; Kenny et al., 2009; Solley et al., 1995).

The non-thermoelectric water demand module projects future water withdrawal and consumption by source (lake, other surface water, and groundwater) and by use sector (municipal, industrial, mining, livestock, and agriculture). Water use statistics published by the USGS serve as the primary data source for the analysis (Kenny et al., 2009; Hutson et al., 2005; Solley et al., 1995; 1990; 1988). Municipal water withdrawal/consumption is calculated as the product of population and the per capita water use. Changes in population are calculated using county level population growth rates reported by the Census Bureau (2009). Rates of change in per capita water withdrawal/consumption are estimated using simple linear regression on data from the USGS (i.e., regressing per capita use with time). Future industrial use is estimated as the product of gross state product (GSP) and water withdrawal/consumption intensity (the volume of water required to produce one dollar of gross state product). Changes in GSP are calculated according to the county level GSP growth rates reported by the U.S. Bureau of Economic Analysis (U.S. Energy Information Administration 2009a). Changes in water intensity are developed from regression of historic data. Future agricultural and mining uses are simply estimated from historic trends.

Decisions concerning future water use have implications for the environmental quality for the Great Lakes region. Two new environmental quality metrics were developed and applied as part of the GLEW model to reveal watersheds in the Great Lakes basin that may be ecologically vulnerable to water withdrawals under certain "low-flow" conditions (Bain 2011). The first metric focuses on the potential for aquatic resource impacts. This metric specifies a portion of surface water flow necessary to sustain desired environmental conditions during low flow periods, using August as an index proxy month for these calculations. This metric was developed as a ratio of streamflow to water withdrawal during the driest time of year (Petts et al. 1999), which is also the time of year when human demand for water is highest - typically the month of August. Based on prior assessments, the metric specified that a $50 \%$ (i.e., a ratio equal to 0.5 ) instream flow was the minimum threshold to maintain aquatic health (Hamilton and Seelbach 2010). Basins having less than 50\% water availability during low flow periods were identified as being vulnerable to significant environmental degradation.

To develop the model, August streamflows for each of the 8-digit watersheds (HUC 8) were taken from Croley (2002). HUC is short for Hydrological Unit Classification, a widely recognized system used to classify watersheds in the U.S. HUC 8 represents the smallest level of categorization for which data were available for this study. Figures for water demand in August were not immediately available, so these were estimated from available annual average water use data (e.g., Kenny et al., 2009), adjusted for peak summer water use. Annual average thermoelectric and industrial uses were increased by 25\% (U.S. Energy Information Administration 2009a) for the month of August to reflect the warmer weather and higher electric power demands and cooling burdens. Irrigation demands were increased by a factor of 4 on the assumption that the majority of irrigation is limited to a 3 month window in the summer. Likewise, municipal use was increased by a factor of 4 to reflect the assumption that almost all outdoor irrigation (as reflected by the consumptive municipal use) is also limited to this 3 month window.

Because temperature fluctuations can have a notable impact on aquatic ecosystems, a second metric was developed to measure the vulnerability of Great Lakes watersheds to thermal loading (e.g., from power generation). The metric is based on the most influential factors that shape thermal conditions: mean annual air temperature, groundwater discharge potential, surface water extent, and riparian forest cover. For each factor, all 102 HUC 8 watersheds were ranked from lowest (most coldwater resource exposed to thermal warming potential) to highest and then converted to a 0-1 scale (Bain 2011). A weighted sum of the four factors was then constructed. The total thermal loading vulnerability was calculated as the product of the aggregate score and the miles of coldwater streams in a given watershed (assuming a mean July temperature of $\left\langle 17.5^{\circ}\right.$ ). Watersheds within the lowest ranking quartile were assigned a high thermal loading vulnerability.

An additional factor considered in our analysis addresses future water use decisions and the impact of these decisions on basin water resources as measured through limits established by the Great Lakes and St. Lawrence River Basin Water Resources Compact (Water Resources Compact). Specifically, the model tracks new power plant construction (built after 2009) that will exceed either Water Resources Compact withdrawal or consumption thresholds for permitting, registration, and/or reporting (Great Lakes and St. Lawrence River Basin Water Resources Compact of 2005; Public Law 110-342). 


\subsection{Environmental Metrics}

Two environmental quality metrics were developed and applied as part of the GLEW model to reveal watersheds in the Great Lakes basin that may be ecologically vulnerable to water withdrawals under certain "low-flow" conditions. The first metric focuses on the potential for aquatic resource impacts. This metric specifies a portion of surface water flow necessary to sustain desired environmental conditions during low flow periods, using August as an index proxy month for these calculations. This metric was developed as a ratio of streamflow to water withdrawal during the driest time of year (i.e., a measure of extent to which water development has impacted streamflow; see Petts et al. 1999), which is also the time of year when human demand for water is highest. Based on prior assessments, the metric specified that a $50 \%$ (i.e., a ratio equal to 0.5 ) instream flow was the minimum threshold to maintain aquatic health (Hamilton and Seelbach 2010). Basins having less than 50\% water availability during low flow periods were identified as being vulnerable to significant environmental degradation.

Because temperature fluctuations can have a notable impact on aquatic ecosystems, a second metric was developed to measure the vulnerability of Great Lakes watersheds to thermal loading (e.g., from power generation). The metric is based on the most influential factors that shape thermal conditions: mean annual air temperature, groundwater discharge potential, surface water extent, and riparian forest cover (values averaged over the HUC 8 watershed). For each factor, all 102 HUC 8 watersheds were ranked from lowest (most coldwater resource exposed to thermal warming potential) to highest and then converted to a $0-1$ scale. A weighted sum of the four factors was then constructed. The total thermal loading vulnerability was calculated as the product of the aggregate score and the miles of coldwater streams in a given watershed (assuming a mean July temperature of $<17.5^{\circ}$ ). Watersheds within the lowest ranking quartile were assigned a high thermal loading vulnerability.

An additional factor considered in our analysis addresses future water use decisions and the impact of these decisions on basin water resources as measured through limits established by the GLSLR Compact (Table 1). Specifically, the model tracks new power plant construction (built after 2009) that will exceed either GLSLR Compact withdrawal or consumption thresholds for permitting, registration, and/or reporting (GLSLR Compact; Public Law 110-342).

\section{Results}

The GLEW model was used to explore the energy-water-environment nexus in the Great Lakes watershed from 2009 to 2035. The scenarios described above serve as five possible alternative futures, each with a different future mix of power plant fuel types and accompanying cooling system. By investigating these alternative futures we are able to quantify the associated tradeoffs of each of these scenarios in terms of water withdrawal, environmental vulnerability, and implications for non-compliance with state and regional water withdrawal and consumption thresholds established by the GLSLR Compact.

\subsection{Regional Water Withdrawal}

Variations in the mix of power plant fuel/cooling types across the five scenarios resulted in different levels of thermoelectric water demand (Figure 1). The highest growth in withdrawal was associated with the BAU case, with a $10.2 \mathrm{Mm}^{3} / \mathrm{d}$ increase, or $10 \%$. For this case, the majority (80\%) of the water would come from the Great Lakes. The next largest increase of withdrawals at $0.14 \mathrm{Mm}^{3} / \mathrm{d}$ for the NNOLC scenario was much lower than the increase under BAU. The RPS case resulted in an overall decrease in withdrawals of $0.11 \mathrm{Mm}^{3} / \mathrm{d}$. This is a function of the very low water use by NGCC and biopower, no water use by wind power, and the retirement of a few plants on the basis of age. Even greater reductions in water withdrawals were realized under the CCS case, which resulted in a reduction of $4.5 \mathrm{Mm}^{3} / \mathrm{d}$ from all water sources. One reason for the large decrease in withdrawals is that compared to the aforementioned scenarios, the CCS case assumes that more plants are retired due to requirements to retrofit these plants in order to achieve the GHG emission reduction target. These retired plants - most of which use open loop cooling - are assumed to be replaced with new plants utilizing closed loop systems.

As expected, the largest reductions in total water withdrawals are associated with the OLCP case, where withdrawals would drop by $87 \%$, or $85.8 \mathrm{Mm}^{3} / \mathrm{d}$. Eighty-two percent of this reduction would be from withdrawals directly from the Great Lakes, as opposed to tributaries or groundwater. The analysis also compared changes in water use from the thermoelectric power sector with other sectors. Results showed that water use is projected to increase in the municipal and industrial sectors by 3.0 and $3.8 \mathrm{Mm}^{3} / \mathrm{d}$, respectively. This growth is relatively small in comparison to the potential range of change in the thermoelectric sector. Although not reflected in the GLEW modeling analysis, industrial sector withdrawals will likely be impacted by the EPA's 
proposed CWA 316(b) regulation discussed above.

Table 1. Great Lakes State Renewable Portfolio Standards (Database of State Renewables and Efficiency, 2013)

\begin{tabular}{ll}
\hline State & Standard \\
\hline Illinois & $25 \%$ by 2025 \\
Indiana & $4 \%$ between $2013 \& 2018 ; 7 \%$ between $2019 \& 2024 ; 10 \%$ by 2025 \\
Michigan & $10 \%$ by 2015 \\
Minnesota & Xcel Energy: $30 \%$ by 2020 Other utilities: $25 \%$ by 2025 \\
New York & $29 \%$ by 2015 \\
Ohio & $12.5 \%$ by 2024 \\
Pennsylvania & $18 \%$ by $2020-2021$ \\
Wisconsin & $10 \%$ by 2015 \\
\hline
\end{tabular}

\subsection{Regional Consumptive Use}

Consumptive water use for thermoelectric generation increased under all five scenarios (Figure 2). The highest increase at $34 \%\left(0.56 \mathrm{Mm}^{3} / \mathrm{d}\right)$ was observed in the CCS scenario. The large increase in consumptive use is because additional water is consumed in the carbon capture and sequestration process. The second highest increase in consumptive use is shown in the NNOLC scenario with a $22 \%$ increase $\left(0.34 \mathrm{Mm}^{3} / \mathrm{d}\right)$, reflecting the higher consumptive use that is associated with closed-loop systems. The OLCP scenario increased consumption by $16 \%\left(0.25 \mathrm{Mm}^{3} / \mathrm{d}\right)$; this relatively low increase is due to the retirement and replacement of older plants with less efficient cooling equipment by new plants with lower consumptive use factors.

While the BAU scenario increased consumption by only $10 \%\left(0.16 \mathrm{Mm}^{3} / \mathrm{d}\right)$, the case with the lowest increase in consumption was the RPS scenario at $8 \%\left(0.13 \mathrm{Mm}^{3} / \mathrm{d}\right)$. This reflects the considerably lower water use associated with NGCC and wind power generation, which uses no water. For all scenarios, the projected increases in consumptive use from the thermoelectric power sector were lower than increases expected in the industrial sector $\left(0.87 \mathrm{Mm}^{3} / \mathrm{d}\right)$ and in the municipal sector $\left(0.4 \mathrm{Mm}^{3} / \mathrm{d}\right)$ in all but the CCS scenario.

It is interesting to note that consumptive use always increased in contrast to withdrawals which decreased in three cases. Decreasing withdrawals were always the result of either the retirement of plants with open-loop cooling systems or the retrofit of these plants to operate with a closed-loop system. Closed loop systems result in more consumption as heat dissipation is achieved through evaporation rather than conduction (see Macknick et al., 2012).

\section{Total Water Withdrawals}

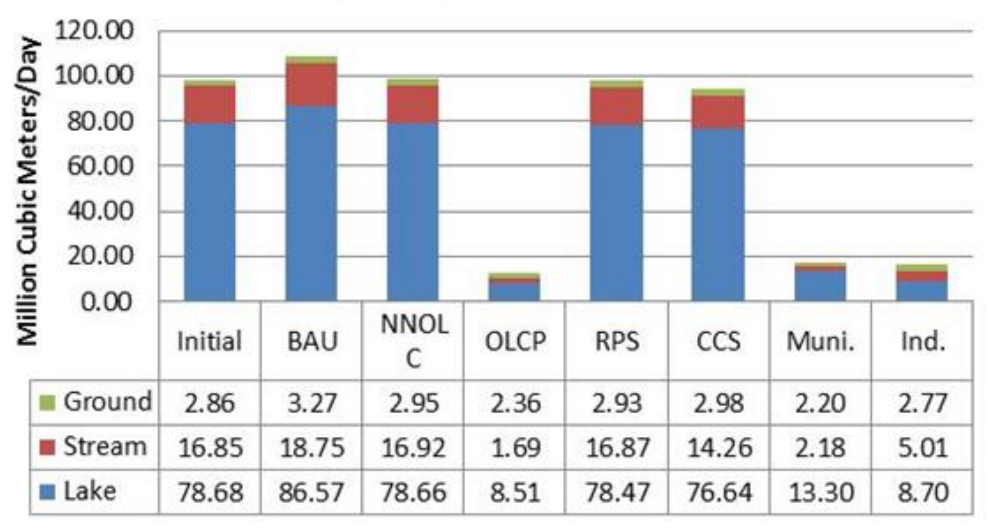




\section{Change in Withdrawal 2009-2035}

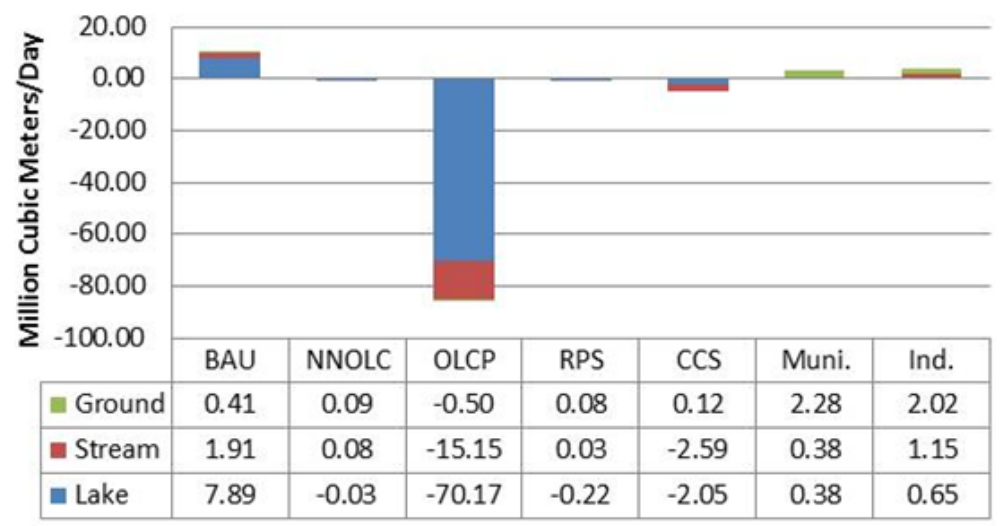

Figure 1. Total water withdrawals by thermoelectric power generation for the five alternative scenarios (top) and the change in water withdrawal between 2009 and 2035 (bottom). Also included are withdrawals by the municipal and industrial sectors. Withdrawals are disaggregated by source (Great Lakes, stream, or groundwater)

\subsection{Impacts on Vulnerable Watersheds}

Environmental metrics used in this analysis identify watersheds in the Great Lakes basin that are subject to low flow and/or thermal loading vulnerability. Figure 3 depicts each of the HUC 8 watersheds ranked as vulnerable (based on 2009 data) with respect to these metrics. According to the low-flow metric, 24 of the 102 watersheds (approximately 25\%) in the Great Lakes basin are classified as vulnerable. In terms of thermal loading vulnerability, 29 watersheds (28\%) are classified as vulnerable. When both are considered, only five watersheds are classified as vulnerable to both low-flow and thermal loading.

The large change in thermoelectric water withdrawal across the five alternative energy futures (Figure 1) has important implications for watersheds vulnerable to low-flow conditions. Depending on the scenarios, the number of watersheds vulnerable to low flow conditions could either increase or decrease by 2035 (Figure 4). Under the BAU scenario, the scenario subject to the greatest new withdrawals, six new basins will achieve vulnerable status. Three new watersheds are deemed vulnerable under the NNOLC and RPS scenarios, while the CCS case gains two newly vulnerable watersheds. In contrast, the OLCP scenario, which included the retirement and/or retrofitting of older plants with open-loop cooling, reduced the number of vulnerable watersheds from 24 to 18 - an improvement of six watersheds.

\section{Total Water Consumption}

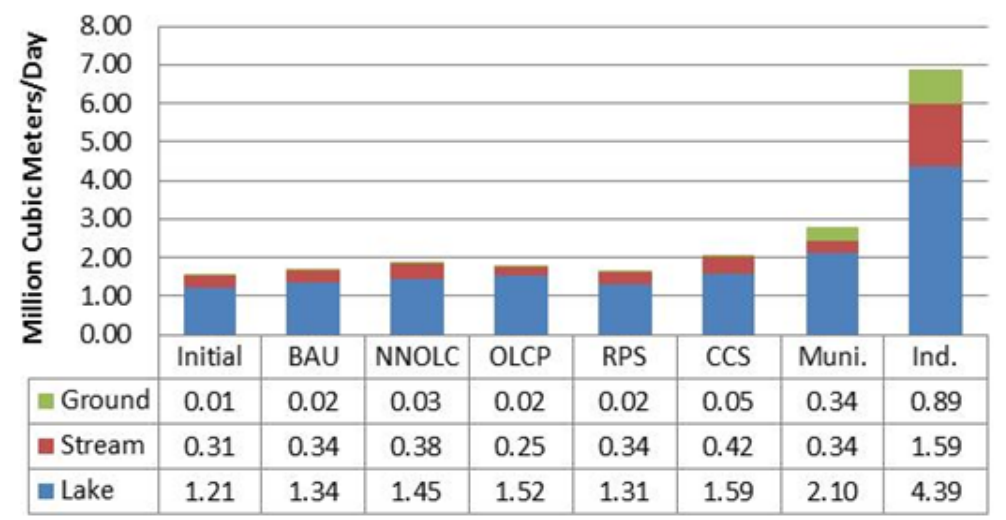




\section{Change in Consumption 2009-2035}

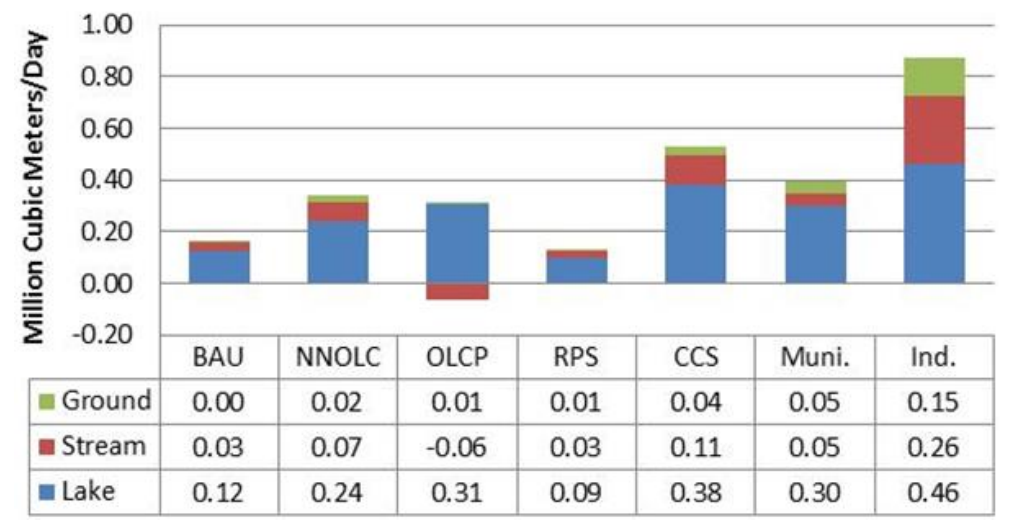

Figure 2. Total water consumption by thermoelectric power generation for the five alternative scenarios (top) and the change in water consumption between 2009 and 2035 (bottom). Also included is consumption by the municipal and industrial sectors. Consumption is disaggregated by source (Great Lakes, stream, or groundwater)

Thermal loading from power plants with open-loop cooling represents an important "coldwater resource threat" (Great Lakes Commission, 2011). A significant number of watersheds, 17 of 29 listed as thermally vulnerable in 2009, had some level of thermoelectric activity. In both the BAU and NNOLC scenarios, seven vulnerable watersheds experienced increased thermoelectric production; however, associated power plant discharges were much higher for the BAU case $\left(0.19 \mathrm{Mm}^{3} / \mathrm{d}\right)$ than for the NNOLC $\left(7.5 \times 10^{-3} \mathrm{Mm}^{3} / \mathrm{d}\right)$ case. Under both the BAU and NNOLC scenarios, two watersheds encounter small decreases in power plant discharge due to the retirement of aging plants. For the OLCP case ten thermally-vulnerable watersheds experience a decrease in thermoelectric water discharge, while six thermally-vulnerable watersheds have small increases in thermoelectric activity (with an average new discharge level of $2.2 \times 10^{-3} \mathrm{Mm}^{3} / \mathrm{d}$ ). Eighteen and seventeen of the thermally vulnerable watersheds experience increased thermoelectric discharge under the RPS and CCS cases respectively. This is due to the large number of gas and biopower plants that would be constructed under this scenario to meet growing demand; however, new discharges are relatively small, averaging $7.5 \times 10^{-4}$ and $2.2 \times 10^{-3} \mathrm{Mm}^{3} / \mathrm{d}$, respectively. The

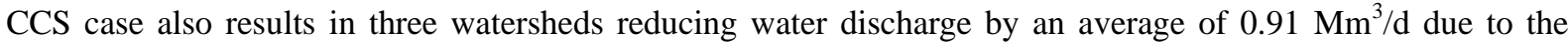
retirement of old coal plants.

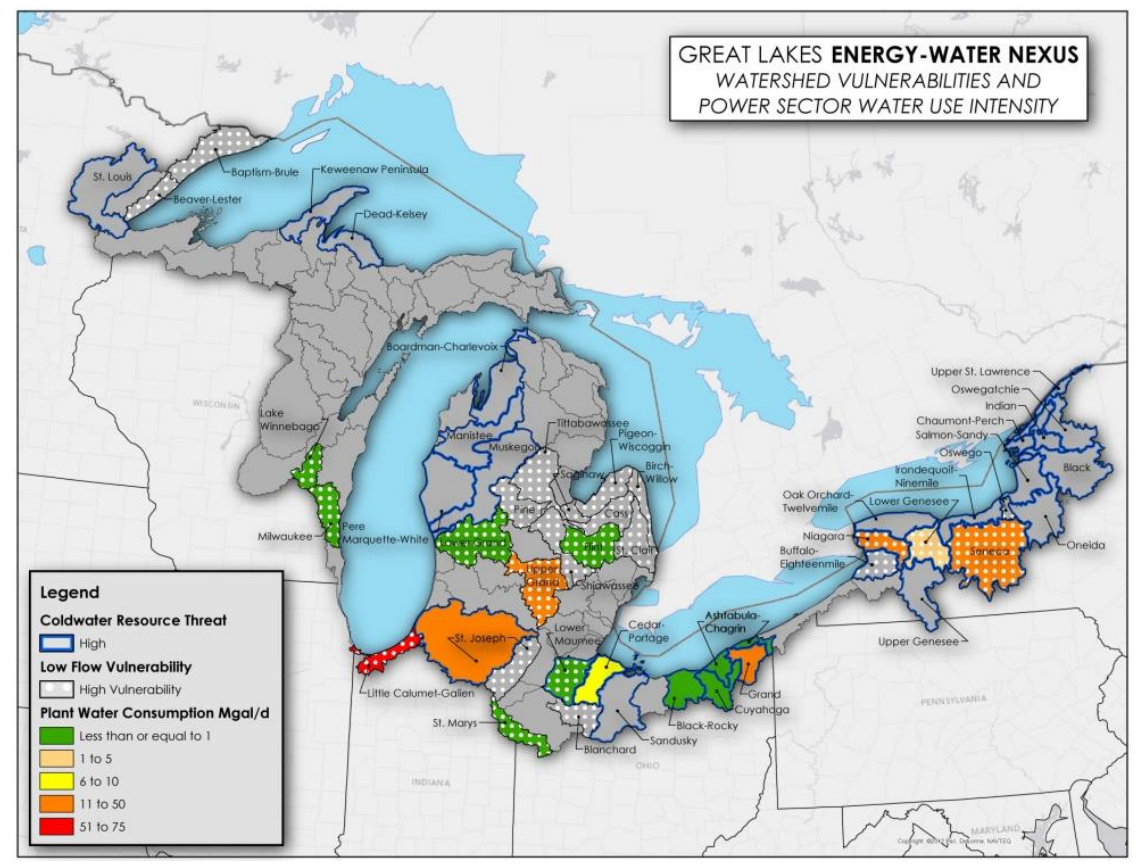

Figure 3. 
3.4 Implications for the GLSLR CompactThis analysis also looked at the potential impact of regulationsassociated with the GLSLR Compact. To explore this issue, we calculated the number of times the GLSLR Compact withdrawal and consumption thresholds established by the GLSLR Compact or individual state implementing legislation are exceeded by a new power plant. We examined and compared the total withdrawal and consumption subject to regulation and permitting for the five future energy scenarios over the entire Great Lakes Watershed. Results indicated that there is a large spread in the number of plants that may require regulation and permitting, ranging from 22 for the NNOLC scenario to 102 for the CCS scenario (Figure 5). The least was associated with the NNOLC and OLCP scenarios, which tend to have the lowest overall withdrawals for reasons described earlier. The BAU scenario had the next largest number at 34 . The RPS and CCS had significantly larger numbers of potentially regulated new withdrawals, at 79 and 102 respectively. This notable increase is due to the much greater increase in the number Figure 3. Watershed Vulnerabilities and Power Sector Water Use Intensity. Source: Great Lakes Commission, 2012.

of plants that would be constructed, and the fact that the primary energy sources under these scenarios, NGCC and biofuels, typically smaller plants with lower capacity factors (relative to coal and nuclear which dominate the new construction for other scenarios).

Fewer plants exceed the GLSLR Compact consumption threshold than the withdrawal threshold (Figure 5) reflecting the generally higher consumption thresholds. Both the NNOLC and OLCP scenarios had the highest number of potentially regulated plants at twelve each. This trend is counter to the withdrawal case because the NNOLC and OLCP cases have higher consumptive use and lower withdrawals due to the shift from open-loop to closed-loop cooling. The BAU scenario had no new plants exceeding the consumption thresholds, largely due to the heavy use of open-loop cooling. The RPS and CCS scenarios had few plants, two each, which exceed consumption thresholds. This is because relatively small and low water use plants are projected for construction.

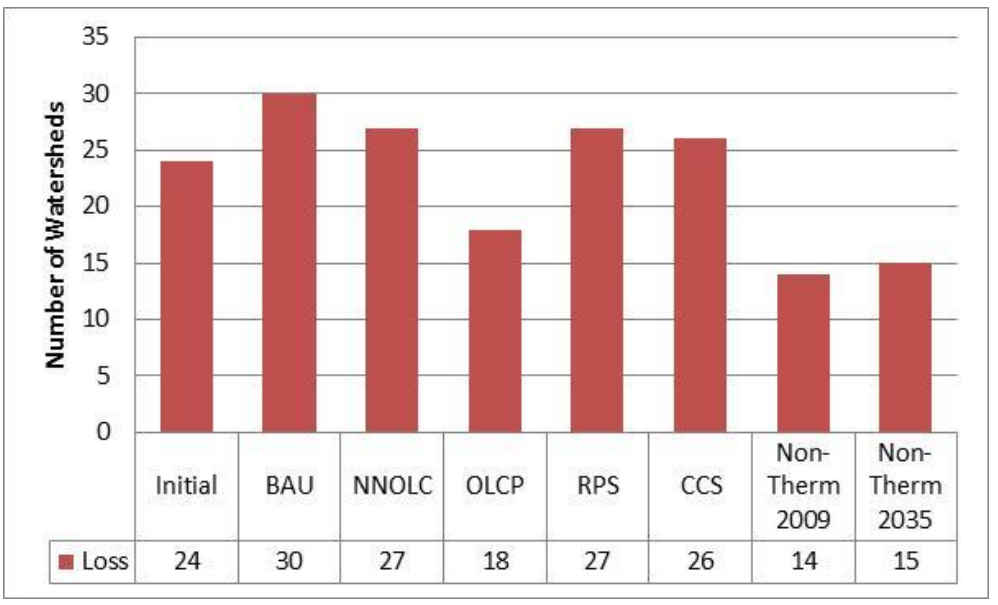

Figure 4. Number of watersheds classified as having vulnerable environmental quality based on the low-flow metric. Bars on the far right indicate the number of vulnerable watersheds if thermoelectric water use is not included in the calculation

\section{Discussion}

For most of its history, electric power grids were designed on the basis of delivering power from large utility-owned power plants to nearby consumers. Consumers generally did not concern themselves with the operation of the power grid, and with little or no competition, utilities made nearly all of the decisions about where to build new plants and transmission lines in their service areas.

Several major policy and technological developments have recently combined to change the grid's operational characteristics and its resulting environmental impacts. These same changes also provide a mechanism for expanded integrated resources planning. For example:

- Inspired by the success of deregulation in the telecommunications industry in lowering prices, some states, including some in the Northeast and Midwest, have restructured their electricity markets to encourage more competition and lower energy prices.

- Utilities in the Northeast, Mid-Atlantic and Midwest formed regional wholesale energy markets known as regional transmission organizations (RTOs) intended to encourage utilities and others to improve grid 
reliability, buy and sell power more efficiently, and plan long-term regional grid expansion in a transparent manner.

- State renewable energy standards in the Midwest and elsewhere are spurring on the development of wind power. The development of wind power in remote areas far from electrical load has consequently increased the need for new transmission lines to deliver the power to market.

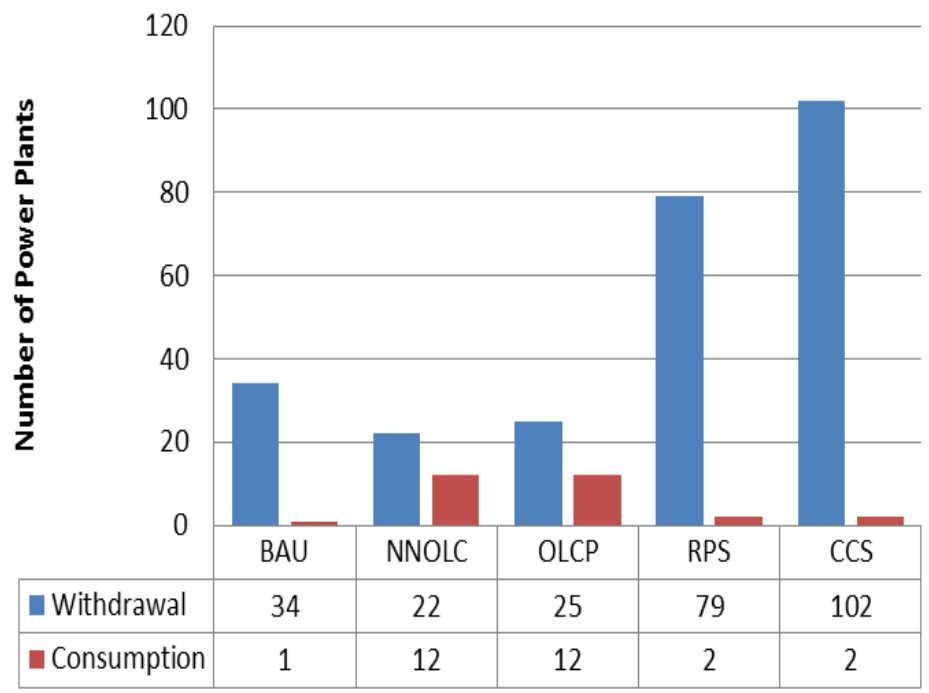

Figure 5. Number of new power plants whose water withdrawal or consumption exceeds the respective threshold for the Great Lakes and St. Lawrence River Basin Water Resources Compact

The Great Lakes region is at the epicenter of these changes. The Great Lakes states (IL, IN, MN, NY, OH, PA and WI) encompass a mix of regulated and restructured retail electricity markets, with three different RTOs operating in the region. Wind power capacity in the Great Lakes states has more than tripled since 2005, fueled in part by state renewable electricity standards and other policies. State energy efficiency standards and other efficiency and "demand response" measures are reducing electric power demand. Natural gas produced from hydraulic fracturing is fueling more power plants. These and other changes are significantly affecting state-regulated resource planning and federally-regulated high power grid planning.

Below we review a couple of these important policy changes and their implications for improved energy and water resource planning.

\subsection{FERC and Order 1000}

The Federal Energy Regulatory Commission (FERC) is the primary federal agency responsible for overseeing the electric power grid. Over the last 16 years FERC has taken a number of steps to improve electric grid reliability, wholesale energy markets and long-term grid planning. In 1996, FERC issued the first of several orders to encourage "open access" of the nation's transmission system and reduce high power costs to ratepayers. Order 888, among the most significant of these orders, required public utilities to allow other power generation to access the utilities' transmission lines, and to offer non-discriminatory tariffs for all users of the transmission system. FERC issued this "open access" order in part to complement state movement in the direction of retail choice and restructured electricity markets (Federal Energy Regulatory Commission 1997).

Concurrent with its open access rules and other changes, in Order 2000 FERC encouraged (but did not mandate) utilities to join wholesale transmission organizations known as regional transmission organizations (RTOs). FERC believed that the regional, RTO-based decision-making was superior, more efficient and cost-effective than utility-by-utility decisions in managing and planning the power grid, and that RTOs reduced economic and other barriers to buying and selling power across longer distances (Federal Energy Regulatory Commission 1999). Order 2000 represented a new FERC boldness to regionalize electric grid operations, planning and markets. While FERC technically already had the authority to authorize the creation of regional power "councils," it was not until FERC Order 2000 that the Commission broadly exercised that authority.

The three RTOs which operate in the Great Lakes region of the United States are Midcontinent Independent System Operator (MISO), PJM Interconnection, and New York ISO (NYISO). MISO and PJM boundaries cross 
through several states, including Illinois, Michigan, Indiana and Ohio. The NYISO covers only the state of New York. The Ontario Independent Electricity System Operator manages transmission grid operations in the Canadian territory contiguous to the Great Lakes.

One of an RTO's primarily responsibilities is long-term electric system planning. MISO, for example, engages in a ten to twenty year forward-looking planning process every 18 months. The end product is an expansion plan listing each new transmission system project approved in the RTO. Approved projects are funded through MISO-imposed fees charged to all users that will benefit from the upgrades. The MISO planning process includes accounting for current and potential future state and federal public policies. MISO's planning process has further evolved in response to the many wind power projects being constructed in the region and the resulting need to deliver the wind power to load centers, usually cities and other high-demand areas.

In mid-2011 FERC issued an important rule on transmission planning and cost recovery for all RTOs and regulated utilities, known as Order 1000. Order 1000 governs regional and inter-regional planning and allocation of costs for many transmission system upgrades (Federal Energy Regulatory Commission 2011). Among its requirements is that all utilities and RTOs must consider the effects of enacted federal and state laws and regulations in long-term transmission planning. FERC's proposed rule for Order 1000 explained how policies could affect transmission expansion, stating:

$[S]$ tate policies to promote increased reliance on renewable energy resources, such as the renewable portfolio standard measures ...accentuate the need for transmission to deliver electricity from location-constrained renewable energy resources to load centers. Other state policies, such as goals for use of energy efficiency or demand response, may lower load forecasts within a given load zone and thereby affect transmission planning determinations (Federal Energy Regulatory Commission 2010).

Recognizing state fears of jurisdictional over-reaching, FERC made clear that the regional grid planning process mandated in Order 1000 "is not the vehicle by which integrated resource planning is conducted; that may be a separate obligation imposed on many public utility transmission providers and under the purview of the states" (Federal Energy Regulatory Commission 2011). Still, Order 1000 creates a valuable opportunity for state resource planners, environmental regulators and state energy offices to use MISO, PJM and NYISO grid planning functions to help meet their own state's energy needs. It also offers several opportunities for the RTOs to evaluate water resource impacts for the purpose of producing results that are regionally cost-effective and account for supply changes caused by new water standards for power plants. Among these pathways are:

- In accordance with Order 1000, the three RTOs should take into account the impacts of the Clean Water Act, the GLSLR Compact, and state laws on long-term grid planning.

- Just as they already do with air pollution (including carbon), the RTOs should start to track the water impacts of power plants in their regions.

- States should hold their utilities accountable for integrating state plans into the MISO, PJM and NYISO grid plans

- Reciprocally, the RTOs give their states the data and other information necessary to develop compatible plans.

- To help catalyze a process that integrates individual plans into a best-fit Great Lakes regional plan and avoid uncoordinated and inefficient state-level efforts, FERC could start by requiring the RTOs to seek and obtain plans from their states, and bring those plans to the regional forum.

\subsection{State Markets and Utility System Planning}

The Interstate Commerce Clause and the Federal Power Act limit FERC's authority over state distribution networks and retail electricity (16 U.S.C. $\S 824(b)(1))$. Depending on their authorizing legislation, state utility commissions regulate such matters as retail power rates, mergers and acquisitions within their states, siting of transmission and generation facilities, and related utility matters (Hempling 2008).

Three states in the Great Lakes region - Indiana, Minnesota and Wisconsin - currently control electricity generation and distribution through regulated energy markets. In these states, utility commissions regulate the retail rates of the electrical industry as a natural monopoly (Bosselman et al., 2006). Vertically integrated utilities own the generation, transmission, and distribution facilities and provide power to customers within their service area. State commissions set the regulated utilities' retail rates and encourage what the commissions perceive to be best practices for electric system operation, such as generation diversification and other attributes of Integrated Resource Planning (IRP) (Brown \& Sedano, 2003).

In states with some form of IRP, commissions have strong legal and policy reasons to encourage utilities to use 
IRP to consider the full evaluation of alternatives, including energy efficiency and renewable energy resources, to provide cost-effective and reliable service. Like FERC Order 1000 discussed above, IRP could and should be a vehicle for more systematic consideration of energy development impacts on water resources. State commissions are in an excellent position to require their utilities to take such impacts into account in the course of their system planning and resource adequacy activities.

By contrast, five states in the Great Lakes region currently operate with "restructured" or "deregulated" energy markets: Illinois, Michigan (more accurately described as "partially restructured" because of state law limits on the extent of deregulation), New York, Ohio, and Pennsylvania. Restructured energy markets are intended to encourage competition in the electric power industry and give consumers a choice of electricity suppliers at the retail level. However, state utility commissions in restructured states have less direct control and fewer supervisory powers over the utilities and independent power producers in their states. Consequently, there may be fewer opportunities in these states for state commissions to influence the impact of power generation on water resources. Nevertheless, state environmental and energy offices can provide valuable input into FERC Order 1000-mandated regional planning processes in the form of information on state laws and regulations impacting water use and other state policies that affect electrical generation and transmission development.

\subsection{Options for Improved Energy and Water Resource Planning}

State utility commissioners generally do not consult with state environmental agencies early in the transmission siting and other energy planning processes. Utility commissions in the Great Lakes region have not prioritized electric power water use, consumption and even water quality as issues for review, except to some extent in the context of siting. Authorizing statutes for the commissions usually do not target environmental quality in general, or water issues in particular, as part of their responsibilities. These issues are usually left for state environmental agencies to consider in the context of permitting and other regulatory approvals, which often occur late in the process after the utility has identified a preferred location for the power plant or transmission line.

The public utility commissions in several states in the Great Lakes region do have some statutory latitude to consider the environment in their decisions. The Illinois Public Utilities Act, for example, establishes environmental quality as a goal of the state commission's regulatory powers, and requires the consideration of the environmental costs of proposed actions with "significant" environmental impacts in applicable regulatory processes [220 ILCS 5/1-102(b)(1)]. Michigan and Illinois also have environmental disclosure statutes requiring utilities to periodically disclose electricity generation sources and certain pollutants associated with each resource. [Id. 5/16-127; Mich. Comp. Laws Ann. 460.10r(3)]. Neither state's public utility laws require reporting on water impacts.

In some states energy planning is required to consider environmental impacts. For example, Minnesota's "environmental externalities" statute requires the MPUC to quantify the environmental costs associated with different forms of power generation and use that data when evaluating and selecting resource options in utility resource plan and certificate of need proceedings. (Minn. Stat. 216B.2422, subd. 3(a)). While the MPUC has established values (in $\$ /$ ton of air pollutant) for each of the criteria pollutants and carbon dioxide, it has not yet considered establishing water quality or quantity values.

To address these gaps in state resource planning, several actions could help state utility commissions give greater weight to water resource impacts in the planning process. For example, to sensitize state commissions to the issues and promote more coordination among different state agencies, state governments should participate more actively in RTO planning activities, and provide more data and input from their environmental, natural resources and utility commission government staff. Second, to the extent that existing laws and standards are insufficient to adequately consider water impacts, laws could be amended to require commissions and environmental agencies to study the direct water quantity and quality impacts of all existing power generation in the state. Commissions also could ask utilities to assess water issues in their integrated resource planning process (in regulated states), and incorporate water quantity and quality impacts in power plant siting proposals.

\section{Conclusion and Policy Implications}

This paper explores how different energy generation portfolios could affect the water resources of the Great Lakes Basin. The suite of power generation scenarios analyzed reflects a range of potential outcomes resulting from the implementation of key national and regional energy and environmental policies for the electric power industry. Important policy implications identified as a result of this analysis include:

1. Several major policy and technological developments in the Great Lakes Basin have recently combined to change the grid's operational characteristics and its resulting environmental impacts. These changes 
are requiring a higher degree of integration between state-regulated resource planning and federally-regulated high power grid planning.

2. Although Order 1000 "is not the vehicle by which integrated resource planning is conducted" (FERC, 2011) it creates a valuable opportunity for state resource planners, environmental regulators and state energy offices to use grid planning functions to help meet state's energy needs. It also offers several opportunities for the RTOs to evaluate water resource impacts for the purpose of producing results that are regionally cost-effective and account for supply changes caused by new water standards for power plants.

3. Restructuring of energy markets provides state commissions fewer opportunities to manage the impact of power generation on water resources. However, state environmental and energy offices can provide valuable input into FERC Order 1000-mandated regional planning processes in the form of information on state laws and regulations impacting water use and other state policies that affect electrical generation and transmission development.

4. State utility commissions can give greater weight to water resource impacts in the planning process by: a) increasing the dialogue on water related issues; b) amending laws to consider water related impacts; and c) ask utilities to assess water issues in their integrated resource planning process (in regulated states), and incorporate water quantity and quality impacts in power plant siting proposals

\section{Acknowledgments}

This paper would not have been possible without the insights and input from Mark Bain (Cornell University), John Moore (NRDC) and Nick Schroeck (Great Lakes Environmental Law Center). This work was funded through a grant to Sandia National Laboratories provided by the Great Lakes Commission. Funding for the broader Great Lakes Commission study upon which this paper is based was provided by the Great Lakes Protection Fund. Sandia National Laboratories is a multi-program laboratory managed and operated by Sandia Corporation, a wholly owned subsidiary of Lockheed Martin Corporation, for the U.S. Department of Energy's National Nuclear Security Administration under contract DE-AC04-94AL85000.

\section{References}

Bain, M. (2011). Great Lakes Energy-Water Nexus Initiative: Environmental Rules to Classify Basins for Sensitivity from Future Energy Development, Report to the Great Lakes Commission, February 16, 2011. Available at: http://glc.org/files/projects/glew/GLEW-Environmental-Rules-Bain-2011.pdf

Bosselman, F., Rossi, J., \& Weaver, J. (2006). Retail Competition in Electric Power, Energy, Economics and the Environment: Cases and Materials. Foundation Press 2d ed., pp. 907.

Brown, M., \& Sedano, R. (2003). A Comprehensive View of U.S. Electric Restructuring with Policy Options for the Future. National Council of Electricity Policy, Washington, DC. Retrieved from http://www.hks.harvard.edu/hepg/Papers/BrownSedano.pdf

Croley, T. E., II (2002). Large Basin Runoff Model, in Singh, V, Frevert, D and Meyer, S. (Eds.), Mathematical Models of Large Watershed Hydrology. Water Resources Publications, Littleton, Colorado, pp. 717-770.

Federal Energy Regulatory Commission (2011). Transmission Planning and Cost Allocation by Transmission Owning and Operating Public Utilities, 136 FERC 61,051; Order 1000. Washington, DC. Retrieved from http://www.ferc.gov/whats-new/comm-meet/2011/072111/E-6.pdf

Federal Energy Regulatory Commission (2010). Transmission Planning and Cost Allocation by Transmission Owning and Operating Public Utilities, 131 FERC 61,253 (Issued June 17, 2010). Washington, DC. Retrieved from http://www.ferc.gov/whats-new/comm-meet/2010/061710/E-9.pdf

Federal Energy Regulatory Commission (1999). Regional Transmission Organizations, FERC 61,285; Order 2000. Washington, DC. Retrieved from http://www.ferc.gov/legal/maj-ord-reg/land-docs/RM99-2A.pdf

Federal Energy Regulatory Commission (1997). Order 888, 3-4; Promoting Wholesale Competition Through Open Access Non-discriminatory Transmission Services by Public Utilities; Recovery of Stranded Costs by Public Utilities and Transmitting Utilities. Washington, DC. Retrieved from http://www.ferc.gov/legal/maj-ord-reg/land-docs/rm95-8p1-000.txt

Great Lakes Commission (2011). Integrating Energy and Water Resources Decision Making in the Great Lakes Basin: An Examination of Future Power Generation Scenarios and Water Resource Impacts. Ann Arbor, MI. Retrieved from http://www.glc.org/energy/glew 
Great Lakes-St. Lawrence River Basin Water Resources Compact of 2005. U.S. Public Law 110-342-October. 3, 2008. Retrieved from http://www.gpo.gov/fdsys/pkg/PLAW-110publ342/pdf/PLAW-110publ342.pdf

Hamilton \& Seelbach (2010). Determining Environmental Limits to Streamflow Depletion Across Michigan. The Book of the States, Council of State Governments, pp. 534-537. Retrieved from http://knowledgecenter.csg.org/kc/system/files/HamiltonSeelbach.pdf

Hempling, S. (2008). Economic Regulatory Jurisdiction in the U.S. Electric Industry: The Electric Industry at a Glance. National Regulatory Research Institute, Silver Spring, MD.

Hutson, S. S., Barber, N. L., Kenny, J. F., Linsey, K. S., Lumia, D. S., \& Maupin, M. A. (2005). Estimated use of water in the United States in 2000. U.S. Geological Survey Circular 1268, Reston, VA. Retrieved from http://pubs.usgs.gov/circ/2004/circ1268/

Kenny, R. F., N. L. Barber, S. S., Hutson, K. S., Linsey, J. K., Lovelace \& Maupin, M. A. (2009). Estimated use of water in the United States in 2005, U.S. Geological Survey Circular 1344, 52p. Retrieved from http://pubs.usgs.gov/circ/1344/

Macknick, J., Newmark, R., Heath, G., \& Hallett, K. C. (2012). Operational water consumption and withdrawal factors for electricity generating technologies: a review of existing literature. Environmental Research Letters. 7(4), 045802. Retrieved from http://iopscience.iop.org/1748-9326/7/4/045802

National Energy Technology Laboratory. (2009). Estimating Freshwater Needs to Meet Future Thermoelectric Generation Requirements, 2009. DOE/NETL-400/2009/1339, Pittsburgh, PA. Retrieved from http://netl.doe.gov/research/energy-analysis/publications/details?pub=dc6a8e2d-7b1e-4bc6-afa2-1c4a174f3 615

National Energy Technology Laboratory (2007). Coal Power Plant Database, Version 2.0., Pittsburg, PA. Retrieved

from http://www.netl.doe.gov/File\%20Library/Research/Energy\%20Analysis/Publications/Carbon_Capture_Ene gis_Clearwater_Report_and_Presentation.pdf

Petts, G. E., Bickerton, M. A., Crawford, C., Lerner, D. N., \& Evans, D. (1999). Flow management to sustain groundwater-dominated stream ecosystems. Hydrological Processes, 13, 497-513. Retrieved from http://onlinelibrary.wiley.com/doi/10.1002/(SICI)1099-1085(19990228)13:3\%3C497::AID-HYP753\%3E3. $0 . \mathrm{CO} ; 2-\mathrm{S} / \mathrm{abstract}$

Solley, W. B., Merk, C. F., \& Pierce, R. R. (1988). Estimated use of water in the United States in 1985. U.S. Geological Survey Circular 1004, Reston, VA. Retrieved from http://pubs.er.usgs.gov/publication/cir1004

Solley, W. B., Pierce, R. R., \& Perlman, H. A. (1990). Estimated use of water in the United States in 1990. U.S. Geological Survey Circular 1081, Reston, VA. Retrieved from http://pubs.er.usgs.gov/publication/cir1081

Solley, W. B., Pierce, R. R., \& Perlman, H. A. (1995). Estimated use of water in the United States in 1995. U.S. Geological Survey Circular 1200, Reston, VA. Retrieved from http://pubs.er.usgs.gov/publication/cir1200

Tidwell, V. C., Kobos, P. H., Malczynski, L. A., Klise, G., \& Castillo, C. R. (2012). Exploring the water-thermoelectric power nexus. Journal of Water Planning and Management, 138(5), 491-501. Retrieved from http://ascelibrary.org/doi/abs/10.1061/(ASCE)WR.1943-5452.0000222

U.S. Census Bureau (2009). Statistical Abstract of the United States: 2008-2009. Available at Retrieved from http://www.census.gov/prod/2008pubs/09statab/pop.pdf

U.S. Energy Information Administration (2009a). Annual Energy Outlook, U.S., 2009. Washington, DC. Retrieved from http://www.eia.gov/oiaf/aeo/pdf/0383(2009).pdf

U.S. Energy Information Administration (2009b). Steam-electric plant operation and design report. Rep. EIA-767, Washington, DC. Retrieved from http://www.eia.gov/electricity/data/eia767/

U.S. Energy Information Administration (2009c). Annual electric generator report. Rep. EIA-860, Washington, DC. Retrieved from http://www.eia.gov/electricity/data/eia860/index.html

U.S. Environmental Protection Agency (2012). Modified Settlement for Proposed Regulations. Retrieved from http://water.epa.gov/lawsregs/lawsguidance/cwa/316b/upload/modified-settlement-agreement-with-Riverke eper.pdf. Washington, DC.

U.S. Environmental Protection Agency (2011). Inventory of U.S. Greenhouse Gas Emissions and Sinks: 1990-2009, EPA-430-R-11-005, Washington, DC, Apr. 15, 2011. Retrieved from 
http://www.epa.gov/climatechange/ghgemissions/usinventoryreport.html

U.S. Environment Protection Agency (2009). EPA Analysis of the American Clean Energy and Security Act of 2009, Washington, DC. Retrieved from http://www.epa.gov/climatechange/Downloads/EPAactivities/HR2454_Analysis.pdf

United States Code, Chapter 12, Title $16 \S 824 \mathrm{a}(\mathrm{a})$, 1920. Federal Power Act. Retrieved from http://www.law.cornell.edu/uscode/text/16/chapter-12

\section{Copyrights}

Copyright for this article is retained by the author(s), with first publication rights granted to the journal.

This is an open-access article distributed under the terms and conditions of the Creative Commons Attribution license (http://creativecommons.org/licenses/by/3.0/). 